\title{
Haida Language
}

National Cancer Institute

\section{Source}

National Cancer Institute. Haida Language. NCI Thesaurus. Code C153941.

A language isolate that is the language of the Haida people, spoken in the Haida Gwaii archipelago off the northern Pacific coast of Canada and on Prince of Wales Island in Alaska. 